\section{Physiological response of soybean seeds to spray volumes of industrial chemical treatment and storage in different environments}

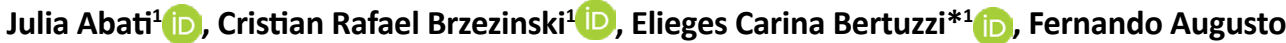 \\ Henning ${ }^{2}$, Claudemir Zucareli ${ }^{1}(i)$
}

\begin{abstract}
The increase in spray volumes in industrial seed treatments may increase the deterioration and reduce the physiological potential of seeds, especially when stored in unfavorable environments. The aim of this study was to evaluate the effect of spray volumes obtained by the combination of different chemical products, via industrial treatment, on the physiological potential of soybean seeds during storage in different environments. A completely randomized experimental design was used in a $5 \times 3$ factorial arrangement, with four replications. The factors were five spray volumes $(0,600,1200,1800$ and $2400 \mathrm{~mL} .100$ $\mathrm{kg}^{-1}$ of seeds), obtained from the combination of different products in commercial use, and three storage periods (0,60 and 120 days), evaluated separately in two environments (storage without climate control and cold storage). The following variables were evaluated: germination, first germination count, seedling emergence in sand, emergence speed index, seedling length (total, shoot, and root) and dry matter (shoot and root). The physiological potential of soybean seeds is reduced by increasing the spray volume used in the industrial treatment and by prolonging the storage period. However, this effect is mitigated by the controlled conditions of cold storage.
\end{abstract}

Index terms: Glycine $\max$ (L.) Merrill, germination, vigor, storage, physiological seed quality.

\section{Resposta fisiológica de sementes de soja a volumes de calda do tratamento químico industrial e armazenamento em diferentes ambientes}

RESUMO: O aumento dos volumes de calda no tratamento industrial de sementes pode aumentar a deterioração e reduzir o potencial fisiológico das sementes, principalmente quando armazenadas em ambientes desfavoráveis. Assim, objetivou-se avaliar o efeito de volumes de calda, obtidos pela combinação de diferentes produtos químicos, via tratamento industrial, sobre o potencial fisiológico de sementes de soja ao longo do armazenamento em diferentes ambientes. $O$ delineamento experimental foi inteiramente casualizado, em esquema fatorial $5 \times 3$, com quatro repetições. Os fatores foram cinco volumes de calda $\left(0,600,1200,1800\right.$ e $2400 \mathrm{~mL} .100 \mathrm{~kg}^{-1}$ de sementes), obtidos a partir da combinação de diferentes produtos comercialmente utilizados, e três períodos de armazenamento $(0$, 60 e 120 dias), avaliados separadamente em dois ambientes (armazém não controlado e câmara fria). As variáveis avaliadas foram: germinação, primeira contagem de germinação, emergência de plântulas em areia, índice de velocidade de emergência, comprimento de plântula (total, parte aérea e raiz) e massa seca (parte aérea e raiz). O potencial fisiológico de sementes de soja é reduzido com o aumento do volume de calda utilizado no tratamento industrial e com o prolongamento do período de armazenamento, no entanto, esse efeito é mitigado pelo armazenamento em condições controladas de câmara fria.

Termos para indexação: Glycine max (L.) Merrill, germinação, vigor, armazenagem, qualidade fisiológica de sementes.
Journal of Seed Science, v.42, e202042002, 2020

http://dx.doi.org/10.1590/23171545v42221062

\author{
*Corresponding author \\ E-mail: eliegescb@gmail.com
}

Received: 3/10/2019. Accepted: 10/21/2019.

\footnotetext{
${ }^{1}$ Departamento de Agronomia Universidade Estadual de Londrina (UEL), Caixa Postal 6001, 86057-970 - Londrina, PR, Brasil.

${ }^{2}$ Embrapa Soja, Caixa Postal 231, 86001-970 - Londrina, PR, Brasil.
} 


\section{INTRODUCTION}

Soybean holds the position of the most important crop in Brazilian agribusiness with prominence in planted area, production, and yield (CONAB, 2018). This creates the need for investments in research, especially to increase availability of cultivars with high yield potential and of quality seeds (Krzyzanowski et al., 2018).

The growth of soybean production in Brazil was preceded by scientific and technological advances. Techniques of production, quality control, storage, and seed treatment have been refined in recent years and have contributed to this rise in the production sector (Krzyzanowski et al., 2018). Due to new technologies linked to seed production, the value of this raw material has increased, with a significant effect on production costs. Consequently, the seed market has been ever more demanding in regard to high quality seeds that perform their function: becoming adult plants with high vigor and yield (Peske, 2017).

In this context, seed treatment has evolved over the past decade (Brzezinski et al., 2017); it has become industrialized and directed to high performance, refining the quality of the seed finish through use of polymers and dry powder that ensures protection of the active ingredient and makes for better flow the time of sowing (Tonin et al., 2014). This process precedes sowing and involves the technique of application of chemical and/or biological products aiming to ensure seed health in the beginning stages of development to promote higher crop yield (Scheeren et al., 2010; Mattioni et al., 2012; Cantarelli et al., 2015). Seed treatment is a widespread practice in Brazilian agriculture - nearly $98 \%$ of soybean and maize seeds are treated with fungicides and/or insecticides to garantee seedling emergence and better crop stand (Nunes, 2016).

There is a range of products available that can be added to the seed through industrial treatments, such as fungicides, insecticides, nematicides, micronutrients, stimulants, inoculants, biological products, and others that provide the seed and plant protection in the initial phase of development (Avelar et al., 2011; Parisi and Medina, 2013; Bertuzzi et al., 2017).

However, in some situations, some active ingredients or interactions among products can lead to reduced germination and vigor and, consequently, reduced seedling establishment as a result of phytotoxicity in the seeds (Taylor and Salanenka, 2012; Alves et al., 2017). In addition, little is known regarding the spray volume applied and its negative effect on the physiological potential over the storage period, since this process normally uses liquid products. An increase in seed moisture content accentuates the deterioration rate, increasing hydrolysis reactions, which may worsen through an increase in temperature, a factor related to the storage environment, which acts directly on intensification of the chemical reactions (Marcos-Filho, 2015; Meneghello, 2014). Therefore, storage in a controlled environment may provide better storability of chemically treated seeds, facilitating conservation and trade logistics.

Conservation of the physiological potential of seeds is vital for the practice and success of seed treatment. The variety of product options with different purposes for use in industrial seed treatment makes this a complex step, and it increases the spray volume necessary to contain all the molecules and adjuvants offered by the seed industry (Nunes, 2016).

Currently, with the increasing demand for industrial seed treatment, many seed companies have worked in an intense way in the short period of time that precedes sowing. This creates the need for results that provide indications of the best spray volume, storage period and environment to better plan this step of production, as well as efforts to reduce costs (Pereira et al., 2018).

Therefore, the aim of this study was to evaluate the effect of spray volumes obtained through the combination of different chemical products, via industrial seed treatment, on the physiological potential of soybean seeds over the storage period in different environments. 


\section{MATERIAL AND METHODS}

The experiment was conducted in the Seed and Grain Technology Center of the Empresa Brasileira de Pesquisa Agropecuária (Embrapa), Embrapa Soja, Londrina, PR, Brazil, in the Seed Physiology and Technology Laboratories on the soybean cultivar BRS 359 RR. This genotype is stable, and does not have a genetic trait of rupture in the seed coat, such as rips or microfissures. The initial quality of the seed lot was $89 \%$ germination, $96 \%$ emergence in sand, and emergence speed index of 25.6.

A completely randomized experimental design was used in a $5 \times 3$ factorial arrangement, with four replications. The factors consisted of five spray volumes used in industrial seed treatment $\left(0,600,1200,1800\right.$ and $2400 \mathrm{~mL}^{100} \mathrm{~kg}^{-1}$ of seeds), obtained from the combination of different products in commercial use, and three storage periods $(0,60$ and 120 days), evaluated separately in two environments (storage without climate control and cold storage). During the experiment, temperature and relative humidity $(\mathrm{RH})$ were monitored in the storage environment without climate control with the Data Logger HT-500 device (Figure 1). In cold storage, the temperature and RH were programmed and maintained at 10 ㅇ $\mathrm{C}$ and $50 \%$, respectively.

To obtain different spray volumes, first the maximum volume to be used was determined and, based on that value, the other volumes were obtained through reduction in the doses of biostimulant, polymer, inoculant and micronutrient (Table 1). The products used were F: fungicides (carbendazim + thiram); I: insecticides (imidacloprid + thiodicarb); N: nematicide (abamectin); M: micronutrients (cobalt, molybdenum and zinc); P: polymer (Peridiam ${ }^{\mathrm{TM}}$ ); B: biostimulant (kinetin + gibberellic acid, such as GA3 + 4-indol-3-ylbutyric acid) and IN: inoculant (Bradyrhizobium japonicum).

Seeds were treated with the assistance of a Batch Modular Coater (BMC) machine, similar to those used in industrial seed treatment (IST), though projected for small seed quantities. After the treatment and storage, the physiological potential of the seeds was determined by the following evaluations:

Germination (G): performed with a hundred seeds per replication, two subsamples of fifty seeds, for a total of four hundred seeds per treatment. The seeds were distributed in rolls of germitest paper towel, moistened with distilled water in the amount of 2.5 times the dry weight of the substrate. After setting them up, the rolls were placed in a seed

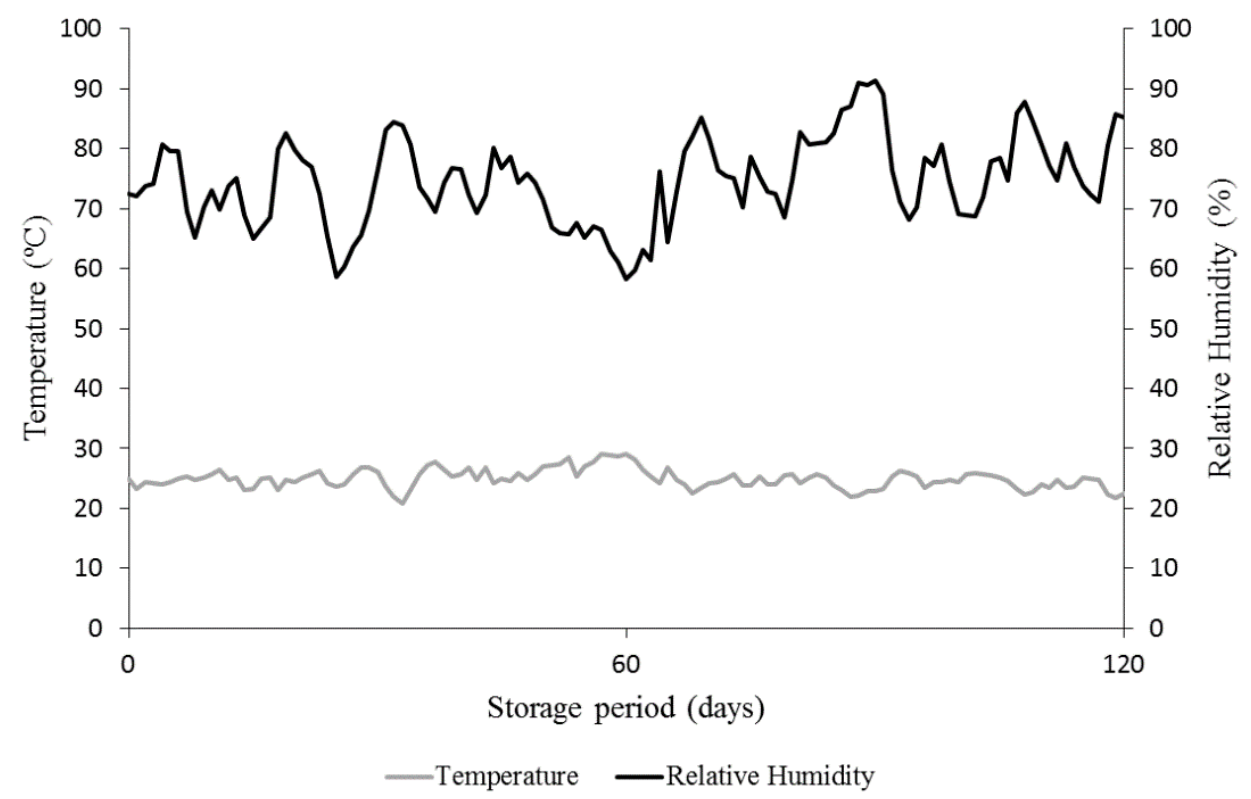

Figure 1. Daily mean of the temperature $(\stackrel{\circ}{-C})$ and relative humidity $(\%)$ throughout the storage period of soybean seeds in an environment without climate control. 
Table 1. Products used in treatment of soybean seeds and respective doses to obtain different spray volumes. Fungicide $(F)$, insecticide (I), nematicide (N), biostimulant (B), micronutrient (M), polymer (P), and inoculant (IN).

\begin{tabular}{ccccccccc}
\hline \multirow{2}{*}{ Treatment } & $\mathrm{F}$ & $\mathrm{I}$ & $\mathrm{N}$ & $\mathrm{M}$ & $\mathrm{P}$ & $\mathrm{B}$ & $\mathrm{IN}$ & Total \\
\cline { 2 - 9 } & & & - & Dose $\mathrm{mL} .100 \mathrm{~kg}^{-1}$ & & 0 \\
\hline 1 & - & - & - & - & - & - & 600 \\
3 & 200 & 300 & 100 & - & - & - & - & 1200 \\
4 & 200 & 300 & 100 & 400 & 200 & - & - & 1800 \\
5 & 200 & 300 & 100 & 400 & 200 & 600 & - & 2400 \\
\hline
\end{tabular}

germinator under the temperature of $25 \stackrel{\circ}{ } \mathrm{C}$ for a period of eight days, at which time the percentage of normal seedlings was calculated (Brasil, 2009).

First germination count (FGC): performed together with the germination test, with evaluation made five days after setting up the test, calculating the percentage of normal seedlings (Brasil, 2009).

Seedling emergence in sand (SE): performed with four hundred seeds per treatment, divided into a-hundred-seed subsamples for each replication. The seeds were sown in plastic trays containing sand into which seeds were placed at a depth of three centimeters. The test was conducted under greenhouse conditions and moisture was maintained through irrigation, according to seedling needs. Final evaluation of the number of normal seedlings emerged was made on day twelve, and the results were expressed in percentage.

Seedling emergence speed index (ESI): performed together with the test of seedling emergence in sand. Evaluations were made daily as of the beginning of emergence, registering the number of seedlings emerged up to day twelve following sowing. Calculation of the emergence speed index was through the equation suggested by Popinigis (1977): $\mathrm{ESI}=\mathrm{N} 1 / \mathrm{D} 1+\mathrm{N} 2 / \mathrm{D} 2+\mathrm{Nn} / \mathrm{Dn}$, where $\mathrm{N} 1=$ number of emerged seedlings on the first day; $\mathrm{Nn}=$ accumulated number of emerged seedlings; $D 1=$ first day of counting and $D n=$ number of days counted after sowing.

Total seedling length ( $\mathrm{SL})$, shoot length (ShL) and root length (RL): five subsamples of twenty seeds each were used, for a total of a hundred seeds per treatment. The seeds were distributed in rolls of paper towel moistened with distilled water in the amount of 2.5 times the weight of the dry paper and then kept in a seed germinator at $25{ }^{\circ} \mathrm{C}$ for five days (Nakagawa, 1999). After that, the total length, shoot length and root length of the normal seedlings were determined with the assistance of a millimeter ruler, and results were expressed in $\mathrm{cm}$ per seedling.

Shoot dry matter (SDM) and root dry matter (RDM): performed with the normal seedlings obtained in the seedling length test, removing the remaining part of the seed and separating the shoot and the root. After that, these parts were placed in paper bags and then in a forced air circulation laboratory oven, where they remained for 24 hours at a temperature of 80 ㅇ (Nakagawa, 1999). At the end of this period, dry matter was evaluated on a scale with precision of $0.0001 \mathrm{~g}$, and results were expressed in grams.

The data obtained were analyzed in regard to normality and homoscedasticity using the Shapiro-Wilk and Hartley tests, respectively, which indicated no need for transformation. Analysis of variance was performed and the mean values for storage periods and spray volume were compared by the Tukey test at $5 \%$ probability separately for each storage environment. Analysis were done by the computational program Sistema para Análise de Variância - SISVAR (System for Analysis of Variance) (Ferreira, 2011).

\section{RESULTS AND DISCUSSION}

The results of analysis of variance indicated a significant effect for the interaction between the storage period and spray volume. There was a different response between the environments evaluated: in the environment of cold 
storage, there was significance in analysis of G, ESI, SE, ShL, and SDM. In the storage environment without climate control, there was significance in all of the tests, except for SDM and RDM (Table 2).

In relation to effects in an isolated manner, spray volume had a similar response between the storage environments. A significant effect was found for first germination count (FGC), germination (G), emergence speed index (ESI), seedling emergence in sand (SE), and shoot length (ShL) for both environments. Analysis of root length (RL), shoot dry matter (SDM), and root dry matter (RDM) did not exhibit change between the two storage situations. Seedling length (SL) in the cold storage was significantly affected by the spray volume. For the isolated effect of the storage period, the effect was significant for all the parameters evaluated, both in the storage environment without climate control and in cold storage (Table 2).

In the cold storage environment, there was no reduction in the values of germination up to sixty days, except for the highest spray volume (Table 3). At the end of 120 days, there were no significant differences only for the control and for the volume of $1800 \mathrm{~mL} .100 \mathrm{~kg}^{-1}$ of seeds.

Comparing spray volumes within each storage period, for all the periods, the control showed better germination results. The percentage of germination decreased according to the increase in the spray volume and over the storage period. This same response is observed for the seedling performance tests (ESI, SE, ShL and SDM), in which the results were also significant for the interaction between spray volume and the storage period (Tables 3, 4 and 5).

Brzezinski et al. (2015) tested early application of the industrial chemical treatment of soybean seeds with the main commercial brands used separately and in combinations of fungicides, insecticides, and nematicides, and they concluded that early treatment of soybean seeds, 240 days before sowing, affects crop establishment, a-thousand-seed weight, and grain yield in relation to treatment in pre-sowing. In addition, the authors found that the chemical treatments tested containing fungicides and insecticides in association improve crop establishment; however, they do not change the yield performance of soybean when used in pre-sowing. This meets the basic aim of the chemical seed treatment, which is to protect seed and seedlings (Scheeren et al., 2010; Krzyzanowski et al., 2018).

For the storage environment without climate control, germination varied over the storage period and among the spray volumes. In the control, germination decreased significantly at 120 days. However, for the treated seeds, as the spray volume increased, reduction intensified, with significant reduction in germination already at sixty days.

Table 2. Values of mean square of analysis of variance of the traits of physiological potential of seeds of the soybean cultivar BRS 359 RR in different environments, storage periods, and spray volumes used in industrial seed treatment.

\begin{tabular}{|c|c|c|c|c|c|c|c|c|c|}
\hline \multicolumn{10}{|c|}{ Cold storage } \\
\hline \multirow{2}{*}{ Source of variation } & \multicolumn{9}{|c|}{ Traits } \\
\hline & FGC & G & ESI & SE & SL & ShL & $\mathrm{RL}$ & SDM & $\mathrm{RDM}$ \\
\hline Period $(\mathrm{P})$ & $339.45 *$ & $729.65^{*}$ & $114.49 *$ & $894.86 *$ & $367.86^{*}$ & $609.04 *$ & $524.86 *$ & $1.48^{*}$ & $0.30^{*}$ \\
\hline Volume (V) & $3160.35^{*}$ & $2147.60 *$ & $126.57^{*}$ & $398.90 *$ & 7.72 & $2.71 *$ & 2.60 & 0.04 & 0.06 \\
\hline $\mathrm{P} * \mathrm{~V}$ & 54.47 & $84.73 *$ & $12.91^{*}$ & $55.26 *$ & 6.07 & $3.31 *$ & 5.16 & $0.07^{*}$ & 0.03 \\
\hline CV (\%) & 11.71 & 9.45 & 6.84 & 3.64 & 6.20 & 6.34 & 10.90 & 9.59 & 26.28 \\
\hline \multicolumn{10}{|c|}{ Storage without climate control } \\
\hline Period (P) & $11069.21 *$ & $12865.26^{*}$ & $1497.36 *$ & $17654.83^{*}$ & $734.60 *$ & $580.56^{*}$ & $601.12 *$ & $2.28 *$ & $0.47^{*}$ \\
\hline Volume (V) & $3932.37^{*}$ & $4562.14^{*}$ & 199.51* & $1704.09 *$ & $22.04 *$ & $11.24^{*}$ & 3.28 & 0.02 & 0.01 \\
\hline $\mathrm{P} * \mathrm{~V}$ & $194.55^{*}$ & $150.82 *$ & $24.39 *$ & $400.59 *$ & $13.77^{*}$ & $4.97 *$ & $6.57^{*}$ & 0.01 & 0.01 \\
\hline CV (\%) & 11.61 & 11.43 & 8.79 & 5.87 & 5.69 & 7.06 & 9.30 & 8.30 & 16.04 \\
\hline
\end{tabular}


Table 3. Germination of soybean seeds of the cultivar BRS 359 RR in different environments, storage periods, and spray volumes used in industrial seed treatment.

\begin{tabular}{cccc}
\hline & \multicolumn{3}{c}{ Cold storage } \\
\hline \multirow{2}{*}{ Spray volume $(\mathrm{mL})$} & 0 & Storage period (days) & 120 \\
\cline { 2 - 4 } & $89 \mathrm{Aa}$ & 60 & $80 \mathrm{Aa}$ \\
0 & $72 \mathrm{Ab}$ & $87 \mathrm{Aa}$ & $59 \mathrm{Bb}$ \\
1200 & $72 \mathrm{Ab}$ & $80 \mathrm{Aa}$ & $58 \mathrm{Bb}$ \\
1800 & $62 \mathrm{Abc}$ & $66 \mathrm{ABb}$ & $54 \mathrm{Abc}$ \\
2400 & $60 \mathrm{Ac}$ & $54 \mathrm{Ac}$ & $45 \mathrm{Bc}$ \\
\hline $\mathrm{CV}(\%)$ & & $47 \mathrm{Bc}$ & \\
\hline & $\mathrm{Storage}$ without climate control & $53 \mathrm{Ba}$ \\
\hline 600 & $89 \mathrm{Aa}$ & $91 \mathrm{Aa}$ & $21 \mathrm{Bb}$ \\
1200 & $72 \mathrm{Ab}$ & $70 \mathrm{Ab}$ & $11 \mathrm{Bbc}$ \\
1800 & $57 \mathrm{Acd}$ & $60 \mathrm{Ab}$ & $8 \mathrm{Cc}$ \\
2400 & $62 \mathrm{Abc}$ & $45 \mathrm{Bc}$ & $1 \mathrm{Cc}$ \\
\hline $\mathrm{CV}(\%)$ & $48 \mathrm{Ad}$ & $30 \mathrm{Bd}$ & \\
\hline
\end{tabular}

Mean values followed by the same uppercase letter in the row and lowercase letter in the column do not differ from each other by the Tukey test at $5 \%$ probability.

Table 4. Emergence speed index of soybean seedlings of the cultivar BRS 359 RR in different storage periods and spray volumes used in industrial seed treatment.

\begin{tabular}{cccc}
\hline & \multicolumn{3}{c}{ Cold storage } \\
\hline \multirow{2}{*}{ Spray volume $(\mathrm{mL})$} & 0 & Storage period (days) & 120 \\
\cline { 2 - 4 } 0 & $25.50 \mathrm{Aa}$ & 60 & $19.13 \mathrm{Bab}$ \\
600 & $25.00 \mathrm{Aa}$ & $26.82 \mathrm{Aa}$ & $19.64 \mathrm{Ba}$ \\
1200 & $19.75 \mathrm{Ab}$ & $20.08 \mathrm{Bb}$ & $15.29 \mathrm{Bc}$ \\
1800 & $19.75 \mathrm{Ab}$ & $16.95 \mathrm{Bc}$ & $16.72 \mathrm{Bbc}$ \\
2400 & $19.25 \mathrm{Ab}$ & $16.10 \mathrm{Bc}$ & $14.74 \mathrm{Bc}$ \\
\hline CV (\%) & & $14.62 \mathrm{Bc}$ & \\
\hline 0 & Storage without climate control & $12.23 \mathrm{Ba}$ \\
600 & $25.61 \mathrm{Aa}$ & $26.71 \mathrm{Aa}$ & $4.75 \mathrm{Bb}$ \\
1200 & $22.78 \mathrm{Ab}$ & $21.74 \mathrm{Ab}$ & $3.81 \mathrm{Cb}$ \\
1800 & $20.03 \mathrm{Acd}$ & $17.32 \mathrm{Bc}$ & $3.18 \mathrm{Cb}$ \\
2400 & $22.01 \mathrm{Abc}$ & $17.56 \mathrm{Bc}$ & $3.37 \mathrm{Cb}$ \\
\hline CV $(\%)$ & $18.64 \mathrm{Ad}$ & $9.51 \mathrm{Bd}$ & \\
\hline
\end{tabular}

Mean values followed by the same uppercase letter in the row and lowercase letter in the column do not differ from each other by the Tukey test at $5 \%$ probability. 
Table 5. Soybean seedling emergence in sand of the cultivar BRS 359 RR in different storage periods and spray volumes used in industrial seed treatment.

\begin{tabular}{cccc}
\hline & \multicolumn{3}{c}{ Cold storage } \\
\hline \multirow{2}{*}{ Spray volume $(\mathrm{mL})$} & \multicolumn{3}{c}{ Storage period (days) } \\
\cline { 2 - 4 } & 0 & 60 & 120 \\
\hline 0 & $96 \mathrm{Aa}$ & $92 \mathrm{Aa}$ & $94 \mathrm{Aab}$ \\
600 & $96 \mathrm{Aa}$ & $83 \mathrm{Bb} \mathrm{Aa}$ \\
1200 & $94 \mathrm{Aab}$ & $78 \mathrm{Cb}$ & $84 \mathrm{Bcd}$ \\
1800 & $88 \mathrm{Ab}$ & $72 \mathrm{Bc}$ & $88 \mathrm{Abc}$ \\
2400 & $89 \mathrm{Ab}$ & $72 \mathrm{Cc}$ & $80 \mathrm{Bd}$ \\
\hline $\mathrm{CV}(\%)$ & & 3.64 & \\
\hline 0 & $\mathrm{Storage} \mathrm{without} \mathrm{climate} \mathrm{control}$ & $68 \mathrm{Ba}$ \\
\hline 600 & $96 \mathrm{Aa}$ & $91 \mathrm{Aa}$ & $33 \mathrm{Cb}$ \\
1200 & $95 \mathrm{Aa}$ & $85 \mathrm{Bab}$ & $28 \mathrm{Cbc}$ \\
1800 & $92 \mathrm{Aab}$ & $79 \mathrm{Bb}$ & $23 \mathrm{Cc}$ \\
2400 & $90 \mathrm{Aab}$ & $81 \mathrm{Bb}$ & $20 \mathrm{Cc}$ \\
\hline $\mathrm{CV}(\%)$ & $84 \mathrm{Ab}$ & $52 \mathrm{Bc}$ & \\
\hline
\end{tabular}

Mean values followed by the same uppercase letter in the row and lowercase letter in the column do not differ from each other by the Tukey test at $5 \%$ probability.

A study with dynamic cooling and storage in a refrigerated and non-refrigerated environment showed that soybean seeds decrease or increase the speed and the intensity of deterioration according to the environment to which they were exposed during storage. The best results for preservation of physiological quality were in an environment at $13^{\circ} \mathrm{C}$ for up to 225 days, which was the longest period evaluated (Ferreira et al., 2017). In the present study, in the storage environment without climate control, there were temperature oscillations, with minimum readings of $21{ }^{\circ} \mathrm{C}$ and maximum readings of approximately $30{ }^{\circ} \mathrm{C}$, with a mean temperature over the storage period of $25{ }^{\circ} \mathrm{C}$. Relative humidity varied from $58 \%$ to $91 \%$, with a mean value of $75 \%$ (Figure 1 ). These conditions explain the greater reduction in seed germination in the storage environment without climate control, especially for the higher spray volumes, in relation to cold storage.

In general, the same response was observed for the tests of FGC, ESI (Table 4), SE (Table 5), SL and ShL (Table 6). For root length for the zero period, a result inferior to the sixty-day period was obtained, but it was equal to or greater than the 120-day period (Table 7). In addition to the storage conditions, the speed of deterioration is affected by genetic factors, the history of seed formation and maturation and post-harvest handling, including storage (Baudet and Villela, 2012; Marcos-Filho, 2015). Other authors concluded that the chemical treatment should be applied near the time of sowing because storage had a negative effect on the physiological quality of maize seeds (Bittencourt et al., 2000; Fessel et al., 2003).

The results obtained may be associated with possible oscillation in the moisture content in accordance with the differences in spray volume of each treatment, which, in general, acted negatively on seed physiological potential. Ludwig et al. (2011) found that after the soybean seed treatments, the moisture content increased a mean of $1 \%$ and that throughout storage without climate control, this parameter oscillated $2.6 \%$ downward in sixty days, rose $0.9 \%$ in 120 days, and once more declined $0.7 \%$ in 180 days of storage. This shows that there is a tendency for seeds, even with seed treatment, to reach hygroscopic equilibrium according to variations in the environment in which they are stored (Baudet and Villela, 2012).

Furthermore, for soybean seeds treated with a single spray volume of $600 \mathrm{~mL} .100 \mathrm{~kg}^{-1}$ of seeds, however, with 
a different active ingredient and mode of action, in storage without control of temperature and relative humidity conditions, a negative effect on seed quality was observed (Ludwig et al., 2011). The same authors found variation among cultivars and among treatment combinations since some interactions led to better seed physiological quality. Segalin et al. (2013) concluded that it is possible to use the treatment in spray volumes of up to $1400 \mathrm{~mL} .100 \mathrm{~kg}^{-1}$ of seeds, without causing physical and physiological damage to the soybean seeds, regardless of the cultivar or the size of the seed. However, they did not evaluate storage time.

For maize seeds, Fessel et al. (2003) found that the treatment with some insecticides reduced germination, and this effect intensified as the storage period went on. Other authors concluded that the reduction in physiological quality varied according to the hybrid tested, the active ingredient of the product used, and the period that the seeds remained in storage (Bittencourt et al., 2000; Bertuzzi et al., 2017).

Furthermore, for the storage environment without climate control, there was interaction between the spray volume and the storage period in the tests of FGC, SL and RL (Table 7), in which the same response described for the other tests predominated. Smaniotto et al. (2014) observed reduction in the physiological potential of seeds stored in an environment without climate control in accordance with the initial moisture content. This helps explain the reduction in physiological potential over the storage period and the drastic reduction in this attribute with the increase in spray volume.

Dan et al. (2010) found that soybean seeds treated with insecticides and stored in an environment without climate control had loss of physiological quality as the storage period increased, in agreement with the results obtained in this study. Tonin et al. (2014) also observed that for maize, the effect of application of insecticide varied in accordance with the genetic characteristics of the hybrid and with the storage conditions, and they highlighted that control of temperature and humidity are crucial to maintain the physiological quality of treated seeds.

Zorato and Henning (2001) obtained a positive effect from fungicide treatment on the quality of soybean seeds during and after the period of ninety days of storage. Dias et al. (2018) evaluated spray volume in soybean seed lots with

Table 6. Shoot length of soybean seedlings of the cultivar BRS 359 RR in different storage periods and spray volumes used in industrial seed treatment.

\begin{tabular}{cccc}
\hline \multicolumn{4}{c}{ Cold storage } \\
\hline \multirow{2}{*}{ Spray volume $(\mathrm{mL})$} & 0 & Storage period (days) & 120 \\
\cline { 2 - 4 } & $20.50 \mathrm{Aab}$ & $11.11 \mathrm{Ba}$ & $10.56 \mathrm{Ba}$ \\
600 & $19.50 \mathrm{Abc}$ & $9.59 \mathrm{Bab}$ & $10.92 \mathrm{Ba}$ \\
1200 & $18.25 \mathrm{Ac}$ & $9.96 \mathrm{Bab}$ & $10.84 \mathrm{Ba}$ \\
1800 & $21.50 \mathrm{Aa}$ & $9.10 \mathrm{Bb}$ & $10.32 \mathrm{Ba}$ \\
2400 & $19.00 \mathrm{Abc}$ & $9.66 \mathrm{Bab}$ & $9.99 \mathrm{Ba}$ \\
\hline $\mathrm{CV}(\%)$ & & 6.34 & $10.42 \mathrm{Ba}$ \\
\hline 0 & Storage without climate control & $8.46 \mathrm{Cbc}$ \\
600 & $20.42 \mathrm{Aa}$ & $10.91 \mathrm{Ba}$ & $8.05 \mathrm{Cc}$ \\
1200 & $20.60 \mathrm{Aa}$ & $10.53 \mathrm{Bab}$ & $8.23 \mathrm{Cc}$ \\
1800 & $17.06 \mathrm{Ab}$ & $10.25 \mathrm{Bab}$ & $10.16 \mathrm{Bab}$ \\
\hline 2400 & $16.69 \mathrm{Ab}$ & $10.01 \mathrm{Bab}$ & \\
\hline CV $(\%)$ & $19.68 \mathrm{Aa}$ & $9.05 \mathrm{Bb}$ & 7.06 \\
\hline
\end{tabular}

Mean values followed by the same uppercase letter in the row and lowercase letter in the column do not differ from each other by the Tukey test at $5 \%$ probability. 
different moisture contents and concluded that seeds with low moisture are affected by the treatment, regardless of the spray volume, and that seeds with intermediate moisture are affected by higher spray volumes. According to Taylor and Salanenka (2012), coating soybean seeds with polymers, alone or in association with fungicide and insecticide, does not delay the speed of imbibition of the seeds.

For the cultivar BRS 359 RR, regardless of the spray volume of the industrial treatment of soybean seeds, there is loss of quality in storage, especially after sixty days. However, with the increase in spray volume, there is a tendency of reducing physiological potential even more, and this may be associated with seed moistening, an increase in metabolic activity and acceleration of deterioration, since the lot used is considered to be of intermediate quality. In general, in the storage environment without climate control, the higher temperature and variations in relative humidity intensify the process of reduction in quality, especially in seeds treated with a higher spray volume. These results suggest that the investment in storage with climate control and adjustments in spray volume can enhance the storage period, attenuating the damage to physiological quality of the seed lots.

Table 7. First germination count of seeds, seedling length, and seedling root length of the soybean cultivar BRS 359 RR in different periods of storage and spray volumes used in industrial seed treatment in a storage environment without climate control.

\begin{tabular}{|c|c|c|c|}
\hline \multicolumn{4}{|c|}{ First germination count of seeds } \\
\hline \multirow{2}{*}{ Spray volume (mL) } & \multicolumn{3}{|c|}{ Storage period (days) } \\
\hline & 0 & 60 & 120 \\
\hline 0 & $79 \mathrm{Aa}$ & $86 \mathrm{Aa}$ & $37 \mathrm{Ba}$ \\
\hline 600 & $59 A b$ & $57 \mathrm{Ab}$ & $12 \mathrm{Bb}$ \\
\hline 1200 & $45 \mathrm{Acd}$ & $49 \mathrm{Abc}$ & $5 \mathrm{Bbc}$ \\
\hline 1800 & $50 \mathrm{Abc}$ & $41 \mathrm{Bc}$ & $4 \mathrm{Cbc}$ \\
\hline 2400 & $38 \mathrm{Ad}$ & $18 \mathrm{Bd}$ & $0 \mathrm{Cd}$ \\
\hline \multirow[t]{2}{*}{ CV (\%) } & \multirow{2}{*}{\multicolumn{2}{|c|}{ Seedling length }} & \\
\hline & & & \\
\hline 0 & 33.16 Aab & $33.51 \mathrm{Aa}$ & $25.76 \mathrm{Ba}$ \\
\hline 600 & $34.25 \mathrm{Aa}$ & $32.89 \mathrm{Aa}$ & $19.42 \mathrm{Bc}$ \\
\hline 1200 & $29.84 \mathrm{BC}$ & $33.10 \mathrm{Aa}$ & $20.88 \mathrm{Cbc}$ \\
\hline 1800 & $30.68 \mathrm{Abc}$ & $31.98 \mathrm{Aa}$ & 19.14 Bc \\
\hline 2400 & 32.29 Aabc & $31.53 \mathrm{Aa}$ & 23.98 Bab \\
\hline \multirow[t]{2}{*}{ CV (\%) } & & 5.69 & \\
\hline & \multicolumn{2}{|c|}{ Seedling root length } & \\
\hline 0 & $12.74 \mathrm{Ca}$ & $22.60 \mathrm{Aa}$ & $15.34 \mathrm{Ba}$ \\
\hline 600 & $13.64 \mathrm{Ba}$ & $22.36 \mathrm{Aa}$ & $10.96 \mathrm{Cb}$ \\
\hline 1200 & $12.78 \mathrm{Ba}$ & $22.85 \mathrm{Aa}$ & 12.83 Bab \\
\hline 1800 & $13.99 \mathrm{Ba}$ & $21.97 \mathrm{Aa}$ & $10.91 \mathrm{Cb}$ \\
\hline 2400 & $12.61 \mathrm{Ba}$ & $22.48 \mathrm{Aa}$ & 13.82 Bab \\
\hline CV (\%) & & 9.30 & \\
\hline
\end{tabular}

Mean values followed by the same uppercase letter in the row and lowercase letter in the column do not differ from each other by the Tukey test at $5 \%$ probability. 


\section{CONCLUSIONS}

The physiological potential of soybean seeds generally decreases with an increase in the spray volume used in the industrial treatment and as the storage period goes on.

The negative effects of the increase in spray volume used in the industrial treatment are mitigated by storage in the climate-controlled environment of cold storage compared to storage without climate control, emphasizing that these results may vary in other genotypes not tested in this study and also depend on the initial physiological quality of the seed lot.

\section{ACKNOWLEDGMENTS}

Our thanks to the Coordenação de Aperfeiçoamento de Pessoal de Nível Superior (CAPES) for granting a scholarship to the first author. Thanks also to the Universidade Estadual de Londrina and to the Empresa Brasileira de Pesquisa Agropecuária (Embrapa Soja) for its structure and financial support in developing this study.

\section{REFERENCES}

ALVES, E.; AGUIAR, E.; PEREIRA, C.; MOREIRA, I.; FILHO, L.; SANTINI, J.M.K. Efeito do tratamento químico com inseticida/fungicida e polímero na qualidade fisiológica da semente de soja. Científic@ - Multidisciplinary Journal, v.4, n.1, p.12-18, 2017. http:// periodicos.unievangelica. edu.br/index.php/cientifica/article/view/2390

AVELAR, S.A.G.; BAUDET, L.; PESKE, S.T.; LUDWIG, M.P.; RIGO, G.A.; CRIZEL, R.L.; OLIVEIRA, S. Armazenamento de sementes de soja tratadas com fungicida, inseticida e micronutriente e recobertas com polímeros líquido e em pó. Ciência Rural, v.41, n.10, p.17191725, 2011. http://www.scielo.br/scielo.php?pid=S0103-84782011001000007\&script=sci_abstract\&tIng =pt

BAUDET, L.; VILLELA, F.A. Armazenamento de sementes. In: PESKE, S.T.; VILLELA, F.A.; MENEGHELLO, G.E. Sementes: fundamentos científicos e tecnológicos. 3. ed. Pelotas: Ed. Universitária/UFPel, 2012. p.481-528.

BERTUZZI, E.C.; MENEGHELLO, G.E.; LEMES, E.; AGUIAR, C.E. Emergência de milho em função do tratamento das sementes com inseticida, fungicida e bioestimulante. In: MENEGHELLO, G.E.; ALMEIDA, A.S.; VILLELA, F.A.; TUNES, L.V.M. Produção técnico científica em sementes - v. I. Pelotas, RS: 2017. p.23-38.

BITTENCOURT, S.R.M.; FERNANDES, M.A.; RIBEIRO, M.C.; VIEIRA, R.D. Desempenho de sementes de milho tratadas com inseticidas sistêmicos. Revista Brasileira de Sementes, v.22, n.2, p.86-93, 2000. https://www.abrates.org.br/files/ artigos/58984c51515df1.07068080_artigo12.pdf

BRASIL. Ministério da Agricultura, Pecuária e Abastecimento. Regras para análise de sementes. Ministério da Agricultura, Pecuária e Abastecimento. Secretaria de Defesa Agropecuária. Brasília: MAPA/ACS, 2009. 395p. http://www.agricultura.gov.br/arq_editor/ file/2946 regras_analise_sementes.pdf

BRZEZINSKI, C.R.; HENNING, A.A.; ABATI, J.; HENNING, F.A.; FRANÇA-NETO, J.B.; KRZYZANOWSKI, F.C.; ZUCARELI, C. Seeds treatment times in the establishment and yield performance of soybean crops. Journal of Seed Science, v.37, n.2, p.147-153, 2015. http:// www.scielo.br/scielo.php?pid=S2317-15372015000200147\&script=sci_arttext

BRZEZINSKI, C.R.; ABATI, J.; HENNING, F.A.; HENNING, A.A.; FRANÇA-NETO, J.B.; KRZYZANOWSKI, F.C.; ZUCARELI, C. Spray volumes in the industrial treatment on the physiological quality of soybean seeds with different levels of vigor. Journal of Seed Science, $\mathrm{v}$. 39, n.2, p.174-181, 2017. http://www.scielo.br/scielo.php?script=sci_arttext\&pid=S2317-15372017000200174\&lng=en\&nrm=iso

CANTARELLI, L.D.; SCHUCH, L.O.B.; RUFINO, C.A.; TAVARES, L.C.; VIEIRA, J.F. Physiological seeds quality: spatial distribution and variability among soybean plant population. Bioscience Journal, v.31, n.2, p.344-351, 2015. http://www.seer.ufu.br/index.php/ biosciencejournal/article/view/22274

CONAB. Companhia Nacional de Abastecimento. Indicadores da agropecuária. Ano XXVII, n6, junho de 2018. 120p. https://www. conab.gov.br/info-agro/precos/revista-indicadores-da-agropecuaria. Accessed on: October 28 ${ }^{\text {th }}, 2018$. 
DAN, L.; DAN, H.; BARROSO, A.; CÂMARA, A.; GUADANIN, E. Efeito de diferentes inseticidas sobre a qualidade fisiológica de sementes de soja. Global Science and Technology, v.3, n.1, p.50-57, 2010. https://rv.ifgoiano.edu.br/periodicos/index.php/gst/ article/view/89

DIAS, M.A.N.; URANO, A.K.M.; SILVA, D.B.; CICERO, S.M. Influence of soybean seed moisture content in the response to seed treatment in soybean. Journal of Neotropical Agriculture, v.5, n.2, p.91-96, 2018. https://periodicosonline.uems.br/index.php/ agrineo/article/view/1415

FERREIRA, F.C.; VILLELA, F.A.; MENEGHELLO, G.E.; SOARES, V.N. Cooling of soybean seeds and physiological quality during storage. Journal of Seed Science, v.39, n.4, p.385-392, 2017. http://www.scielo.br/scielo.php?pid=S2317-15372017000400385\&script=sci_ arttext

FERREIRA, D.F. Sisvar: a computer statistical analysis system. Ciência e Agrotecnologia, v.35, n.6, p.1039-1042, 2011. http://www. scielo.br/pdf/cagro/v35n6/a01v35n6.pdf

FESSEL, S.A.; MENDONÇA, E.A.F.; CARVALHO, R.V.; VIEIRA, R.D. Efeito do tratamento químico sobre a conservação de sementes de milho durante o armazenamento. Revista Brasileira de Sementes, v.25, n.1, p.25-28, 2003. http://www.scielo.br/pdf/rbs/ v25n1/19626.pdf

KRZYZANOWSKI, F.C.; FRANÇA-NETO, J.B.; HENNING, A.A. A alta qualidade de sementes de soja: fator importante para a produção da cultura. Circular Técnica 136. 1. ed. Londrina: Embrapa Soja, 2018. 24p. https://www.infoteca.cnptia.embrapa.br/infoteca/ handle/doc/1091765

LUDWIG, M.P.; LUCCA FILHO, O.A.; BAUDET, L.; DUTRA, L.M.C.; AVELAR, S.A.G.; CRIZEL, R.L. Qualidade de sementes de soja armazenadas após recobrimento com aminoácido, polímero, fungicida e inseticida. Revista Brasileira de Sementes, v.33, n.3, p.395406, 2011. http://www.scielo.br/scielo.php?script=sci_arttext\&pid=S0101-31222011000300002

MARCOS-FILHO, J. Fisiologia de sementes de plantas cultivadas. 2. ed. Londrina: ABRATES, 2015. 660p.

MATTIONI, F.; ALBUQUERQUE, M.C.F.; MARCOS-FILHO, J.; GUIMARÃES, S.C. Vigor de sementes e desempenho agronômico de plantas de algodão. Revista Brasileira de Sementes, v.34, n.1, p.108-116, 2012. http://www.scielo.br/pdf/rbs/v34n1/a14v34n1.pdf

MENEGHELLO, G.E. Qualidade de sementes: umidade e temperatura. Seed News, v.18, n.6, p.28-33, 2014. https://seednews.com. br/edicoes/artigo/258-qualidade-de-sementes:-umidade-e-temperatura-edicao-novembro-2014

NAKAGAWA, J. Testes de vigor baseados no desempenho das plântulas. In: KRZYZANOWSKI, F.C.; VIEIRA, R.D.; FRANÇA-NETO, J.B. (ed.). Vigor de sementes: conceitos e testes. Londrina: ABRATES, 1999. p.2-24.

NUNES, J.C.S. Tratamento de sementes de soja como um processo industrial no Brasil. Seed News, v.20, n.1, p.26-32, 2016. https://seednews.com.br/edicoes/artigo/334-tratamento-de-sementes-de-soja-como-um-processo-industrial-no-brasil-edicaojaneiro-2016

PEREIRA, L.C.; MATERA, T.C.; BRACCINI, A.L.; PEREIRA, R.C.; MARTELI, D.C.V.; SUZUKAWA, A.K.; PIANA, S.C.; FERRI, G.C.; CORREIA, L.V. Addition of biostimulant to the industrial treatment of soybean seeds: physiological quality and yield after storage. Journal of Seed Science, v.40, n.4, p.442-449, 2018. http://www.scielo.br/scielo.php?script=sci_arttext\&pid=S2317-15372018000400442\&ln $\mathrm{g}=\mathrm{en} \& \mathrm{nrm}=\mathrm{iso}$

PARISI, J.J.D.; MEDINA, P.F. Tratamento de sementes. Campinas, SP: Instituto Agronômico, 2013. p.7. http://www.iac.sp.gov.br/ imagem_informacoestecnologicas/81.pdf

PESKE, S.T. Dinâmica do mercado de sementes no Brasil. Seed News, ed. especial XX CBS 2017, n.5, p.12-15, 2017.

POPINIGIS, F. Fisiologia da semente. Brasília, DF: AGIPLAN, 1977. 289p.

SCHEEREN, B.R.; PESKE, S.T.; SCHUCH, L.O.B.; BARROS, A.C.A. Qualidade fisiológica e produtividade de sementes de soja. Revista Brasileira de sementes, v.32, n.3, p.35-41, 2010. http://www.scielo.br/scielo.php?script=sci_arttext\&pid=S0101$31222010000300004 \& \operatorname{lng}=\mathrm{en} \& \mathrm{nrm}=\mathrm{iso}$

SEGALIN, S.R.; BARBIERI, A.P.P.; HUTH, C.; BECHE, M.; MATTIONI, N.M.; MERTZ, L.M. Physiological quality of soybean seeds treated with different spray volumes. Journal of Seed Science, v.35, n.4, p.501-509, 2013. http://www.scielo.br/scielo.php?script=sci_ arttext\&pid=S2317-15372013000400012\&lng=en\&nrm=iso 
SMANIOTTO, T.A.S.; RESENDE, O.; MARÇAL, K.A.F.; OLIVEIRA, D.E.C.; SIMON, G.A. Qualidade fisiológica das sementes de soja armazenadas em diferentes condições. Revista Brasileira de Engenharia Agrícola e Ambiental, v.18, n.4, p.446-453, 2014. http:// www.agriambi.com.br/revista/v18n04/v18n04a13.pdf

TAYLOR, A.G.; SALANENKA, Y.A. Seed treatments: phytotoxicity amelioration and tracer uptake. Seed Science Research, v.22, n.1, p.86-90, 2012. https://doi.org/10.1017/S0960258511000389

TONIN, R.F.B.; LUCCA FILHO, O.A.; BAUDET LABBE, L.M..; ROSSETTO, M. Potencial fisiológico de sementes de milho híbrido tratadas com inseticidas e armazenadas em duas condições de ambiente. Scientia Agropecuaria, v.5, n.1, p.7-16, 2014. http://www.scielo. org.pe/scielo.php? script=sci_arttext\&pid=S2077-99172014000100001\&lng=es\& nrm=iso

ZORATO, M.F.; HENNING, A.A. Influência de tratamentos fungicidas antecipados, aplicados em diferentes épocas de armazenamento, sobre a qualidade de sementes de soja. Revista Brasileira de Sementes, v.23, n.2, p.236-244, 2001. https://ainfo.cnptia.embrapa. br/digital/bitstream/item/49557/1/ABRATES2.PDF use, distribution, and reproduction in any medium, provided the original work is properly cited. 